\title{
ENVIRONMENTAL CERTIFICATION SCHEMES AND PROPERTY VALUES: EVIDENCE FROM THE HONG KONG PRIME COMMERCIAL OFFICE MARKET
}

\author{
Jayantha WADU MESTHRIGE*, Hoi-Ting CHAN \\ Department of Building and Real Estate, The Hong Kong Polytechnic University, Kowloon, Hong Kong, China
}

Received 24 April 2017; accepted 27 April 2018

\begin{abstract}
A barrier to green-building development is the uncertainty and scepticism about the financial implications. This study aimed to investigate whether the green-certification schemes help buyers to recognize the benefits of green office buildings by their willingness to pay a premium for such buildings. The study used a hedonic-model based on a sample of 67 prime office buildings (including non-green comparables) certified by HKBEAM, BEAM-Plus and LEED in Hong Kong. The empirical findings suggest that green certification schemes add extra value to an office property. The rental value of office properties certified by HKBEAM, BEAM Plus and LEED is about $10.9 \%$ higher than for non-certified office buildings. More specifically, tenants/users are willing to pay a premium of $10.9 \%$ for green-certified office properties. The findings have practical implications in encouraging green building development in Hong Kong and elsewhere. The findings indicate that the higher rental income from green office buildings can cover the additional cost of obtaining green certification within a period of 22-months (22.32 months) in Hong Kong. The results provide references for various stakeholders (developers/investors/users) in establishing the business case for green-office buildings, because of the ability of the market to capitalize the environmental benefits of green office properties.
\end{abstract}

Keywords: green certification, office rental value, green-premium, HK-BEAM, BEAM Plus and LEED.

\section{Introduction}

In order to address climate change and global warming issues, policy makers and property investors consider buildings as one of the most important vehicles (Chegut, Eichholtz, \& Kok, 2014), as buildings account for nearly one-third of overall $\mathrm{CO}_{2}$ emissions and constitute the largest climate change offender. Similarly, buildings also possess great potential for green-house gas (GHG) abatement (Heinzle, Yip, \& Xing, 2013). As increasing demands to address climate change and global warming are voiced, the entire real estate industry has an imperative role to play in achieving energy efficiency (Wadu Mesthrige \& Wan, 2013), GHG emissions abatement and corporate social responsibility (CSR) in realizing a low-carbon society. Numerous organizations, particularly in the real estate and construction sector are setting targets for themselves to minimize the environmental impact of the various activities they perform in order to demonstrate that their CSR credentials are in line with broader sustainability goals.

There is however, a notable degree of uncertainty and scepticism underlying the financial implications of green buildings, and this is considered to be a barrier to their development. Researchers believe this is mainly due to the misalignment of incentives for green buildings or a "vicious circle of blame" (Falkenbach, Lindhol, \& Schleich, 2010; RICS, 2008). Investors' reluctance to pay additional costs for green buildings often prevents developers from constructing green buildings. The reluctance of investors stems from their perception that there is insufficient demand for green buildings from property buyers. Hence, construction firms are barred from constructing those properties as developers do not want them to do so (Heinzle et al., 2013). As a result, those property buyers, who are willing to buy or rent green properties, are frustrated by the insufficient supply (Heinzle et al., 2013). This is known as "asymmetry of incentives" among stakeholders, or 'vicious circle of blame' (Falkenbach et al., 2010).

One way to address this incentive gap is to disclose and disseminate information about the environmental performance of buildings. This incentive asymmetry can be overcome through dissemination of environmental information about buildings (Reichardt, Fuerst, Rottke,

*Corresponding author. E-mail: bsmjwadu@polyu.edu.hk 
\& Zietz, 2012). Various professional building assessment schemes and awards have been introduced across the globe to overcome this information asymmetry over the years. In line with the growing interest in various environmental building rating schemes and certifications, Hong Kong has also initiated various green incentive schemes over the past two decades. For example, in order to promote and guide stakeholders in the real estate market towards the best sustainable practices, private and government sectors in Hong Kong have developed a series of professional assessment schemes and practice codes (Jones Lang LaSalle, 2009). Many stakeholders still consider that green buildings and sustainable buildings are synonyms. Green buildings include only environmental aspects. The sustainable building concept however is much broader and include several classes of criteria related to environmental, societal and economic aspects (Haapio \& Viitaniemi, 2008; Castro, Mateus, \& Bragança, 2015; Raslanas, Kliukas, \& Stasiukynas, 2016). Although within the context of Hong Kong, there are different challenges to develop a green building project including high rise dense urban morphology, intensive use of air-conditioning, artificial lighting and lack of concerns for water and electricity saving (Gou \& Lau, 2014). Several government initiatives over the past decade to encourage property developers to incorporate more green features are: (1) the standard environmental performance system (ISO 14001), which was initiated by the Hong Kong Quality Assurance Agency (HKQAA); (2) Indoor Air Quality (IAQ) rating scheme, implemented by the Environmental Protection Department (EDP); (3) the Buildings Energy Codes (BECs), initiated by the Hong Kong Electrical and Mechanical Services Department (EMSD); and the Joint Practice Notes 1 (JPN1) and 2 (JPN2), jointly implemented by the Buildings Department (BD), the Lands Department (LD) and the Planning Department (PD).

Besides these government initiatives, in order to provide greater recognition and better awareness of the benefits of green buildings, various non-governmental organizations have also introduced numerous green building certification schemes and awards. Three such locally well-schemes are:

a) The HK-BEAM (Hong Kong Building Environmental Assessment Method) Certificate by the HKBEAM Society Limited - since 1996.

b) The BEAM Plus Certificate by the HKBEAM Society Limited - since April 2010.

c) The Green Building Award by the Hong Kong Green Building Council - since 2006.

In addition to these local certification schemes, the LEED (Leadership in Energy and Environmental Design), well-known green-building certification scheme initiated by the US Green Building Council is also famous and well received by the construction industry in Hong Kong. Likewise, well known other overseas certifications include, BREEAM (Building Research Establishment's Environmental Assessment Method) in the UK, and CASBEE (Comprehensive Assessment System for Built Environ- ment Efficiency) in Japan. Certainly, real estate provider stakeholders would see all these initiatives as incentives to incorporate more green elements into their new developments. Despite these initiatives, however financial benefits and other implications of green building developments, relative to conventional buildings are not yet certain. As the cost premium for a green development is relatively high, questions arise about the effects of green developments on the cost-benefit ratio (Shimizu, 2010). Compared to conventional buildings, the green development cost premium is in the range of $5-20 \%$ (Gomez, 2008). Miller, Spivey, and Florance (2008), and Kats (2006) report a cost premium of 2-4\%; whilst Kats (2003) also reports that it costs $1.8 \%$ more to design and develop environmentally friendly buildings. Hence, investors and developers often question the financial implications of green design and buildings. In particular, they are uncertain whether incorporating green elements into property developments would actually enhance building occupancy, rents and selling prices (Wiley, Benefield, \& Johnson, 2010).

Previous researchers have critically analyzed and compared application of different sustainability assessment methods including LEED, BREEAM, CASBEE and Green Star etc. in different types of buildings. For example, in general buildings (Haapio \& Viitaniemi, 2008), office buildings (Lee \& Burnett, 2008), public residential design schemes (Gou \& Lau, 2014), healthcare buildings (Castro et al., 2015), and recreational buildings (Raslanas et al., 2016). Gou and Lau (2014) demonstrated that thermal performance of a building's envelop is largely ignored in the Hong Kong building codes and green building rating system. Due to different environmental requirements and evaluation criteria not all sustainability assessment methods could be applied to a variety of buildings and most of the methods are not covering social and economic aspects (Raslanas et al., 2016). Recently few researchers have highlighted the importance and the potential for revenue premiums in various green certification systems in the US, the UK and Australia (e.g., Robinson, Simons, Lee, \& Kern, 2016; Robinson \& Sanderford, 2016; Robinson \& McAllister, 2015). However, the present study is unique, in the sense of being the first covered with commercial properties in Hong Kong, and because it is a comprehensive study in the high-rise context in Asia. This is significant as the Asian perception about the living and working in a green building may differ substantially in substance from the Western perception. In Asia, economics still precedence over sustainability goals; and factors such as location and accessibility may be the primary considerations rather than green features in the choice of a commercial buildings (Addae-Dapaah \& Chieh, 2011). Secondly, awareness and attitudes towards green buildings in the market and among people in Asia are still at an early stage. A comprehensive analysis of the impact of green certification schemes in Asia is therefore a pre-requisite if we are to encourage investors/developers to incorporate green elements/practices in property development. For Hong Kong, hardly any research has been done on the 
commercial office property market. Thirdly, Hong Kong is a high-density compact city with few green and open spaces, very different from the US and the UK contexts. Fourthly, only very limited knowledge and information is available about the demand for green commercial office buildings, particularly on the premium that property buyers and users would be willing to pay for green certification. This study aims to fill this research gap by answering two questions: (i) "Would buyers be willing to recognize the benefits of green buildings by paying a premium for them?"; and (ii) "How would the market value green commercial office buildings?". It is hypothesized that green certifications would help to address "incentive asymmetry" among real estate stakeholders, and act as incentives to offset the higher green development costs by narrowing the disparity between cost and benefit. Fifthly, this study addressed the weaknesses due to the omitted variables issue in hedonic price modelling, by adopting a fixed effects approach to reduce biases among the estimates.

In the study, commercial office properties certified by HK-BEAM, BEAM Plus and LEED were recognized as "green buildings". These are awarded by the HK-BEAM Society Limited and the US Green Building Council, respectively. In the study, bases of property value is specified according to the definition given by the International Valuation Standards Council [IVSC], 2017: Market Value (Section 30), Market Rent (Section 40), Equitable Value (Section 50), Investment Value (Section 60). The scope of the study was limited to private commercial office developments as market forces determine the prices of private properties, whereas in the public sector market signals are not that efficient. Section 1, below, provides an overview of the sustainable initiatives with special reference to construction and real estate industry, along with a review of previous studies mainly of environmental certification schemes in the commercial property market. Thereafter, Section 2 describes the data sources, including the modelling of the hedonic price method (HPM). The penultimate section analyzes the empirical results obtained from the HPM, while the last section concludes with findings and implications.

\section{Literature review}

\subsection{Hong Kong context: trends and sustainable initiatives}

Over the last two decades, an increasing trend has emerged in that organizations and governments all over the world are seriously concerned about the natural and social environment in which they work and live (Wetering \& Wyatt, 2011). There are a number of reasons for this, but climate change and global warming is a prominent concern, which the real estate and construction industry has an imperative role to play in addressing and achieving energy efficiency and carbon abatement in the realization of a low-carbon society. The construction industry, in particular new construction, has an adverse impact on the environment as it consumes a vast amount of energy resources (Dimoudi \& Tompa, 2008; Mohammad \& Amato, 2006). The life cycle of this industry, which includes construction, operation, maintenance and demolition, consumes around half of the total energy demand, and is also responsible for a significant amount of GHG, and almost $50 \%$ of the $\mathrm{CO}_{2}$ emissions to the environment (Yan, Shen, Fan, Wang, \& Zhang, 2010; Dimoudi \& Tompa, 2008).

While the building industry globally accounts for a little more than $1 / 3$ of GHG emissions, the figure for Hong Kong is remarkably high; at nearly 70\% (WBCSD, 2008). This is mainly due to heating and cooling, especially the air-conditioning and the lighting and ventilation of buildings (Metha, 2007). The building industry in Hong Kong is responsible for the largest component of energy consumption accounting for the largest GHG emissions (Gorer, Lawson, Loh, Botelho, \& Leao, 2008). Key sustainability elements of the building sector in general and the commercial sector in particular need to be clearly studied and integrated in order to fully implement sustainable development goals of Hong Kong (Mohammad \& Amato, 2006). The commercial office sector in Hong Kong is a major constituent of the building industry, particularly in relation to operational energy consumption. As seen in Figure 1, the operational energy consumption of the commercial sector (compared to other sectors) is very high, and shows an increasing trend over the last two decades. In other words, the commercial sector is responsible for most of the electricity consumption in the built environment in Hong Kong. According to the Environment Bureau (2011), buildings electricity consumption accounts for $60 \%$ of Hong Kong's total GHG emissions; and in 2008, commercial buildings alone were responsible for $65 \%$ of the total energy consumption of buildings. This clearly demonstrates that office buildings, as the main constituent of the commercial sector, contribute largely to GHG emissions in Hong Kong. Therefore, the commercial office sector in particular has a pivotal role to play in the realization of a sustainable built environment and a lowcarbon society.

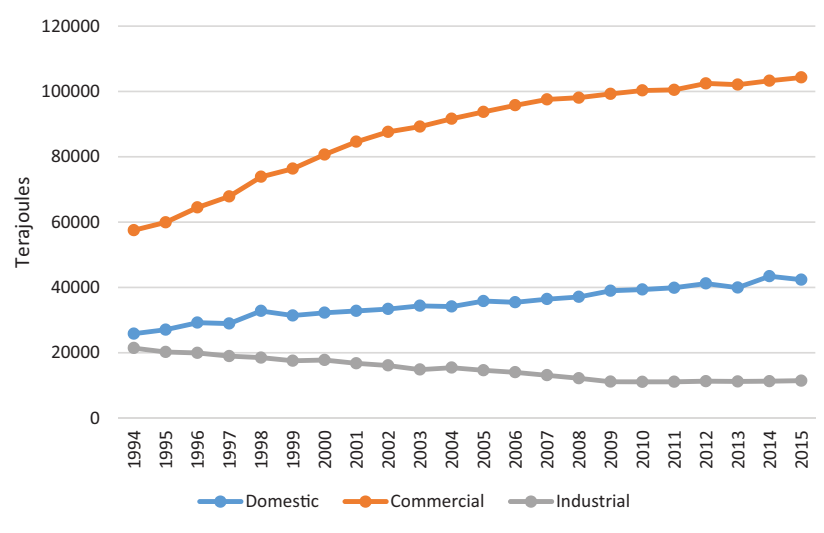

Figure 1. Sectoral breakdown of electricity consumption 19942015 (sources: Census and Statistics Department, Hong Kong Energy Statistics-Annual Reports (various issues)) 


\section{Sustainable initiatives}

Over the past two decades, the global ideas of a "lowcarbon society" and "sustainable development" have been at the forefront in the main global forums. In line with the global trend of setting targets to minimize the environmental impact of buildings, the real estate sector in Hong Kong over the past few years has began to appreciate the importance of labelling the environmental performance of buildings. For example, numerous building assessment schemes, codes and ratings have been put in place to encourage real estate stakeholders to practice best sustainability principles (Jones Lang LaSalle, 2009). The Hong Kong government, demonstrating its commitment in line with "Agenda 21", has been very active in identifying and implementing various policies and mechanisms for achieving overall sustainable development goals (Chan, Esther, \& Yung, 2004). However, the majority of these initiatives and incentives to enhance sustainability practices are voluntary.

An early government initiative was the Considerate Contractors Site Award Scheme (CSAS), set up in 1995. This was jointly initiated with the Development Bureau (DevB) with the intention of promoting awareness of good site safety and health and environmental practices on construction sites (HKSAR Development Bureau, 2011). Similarly, in another significant move to provide builders with incentives to incorporate new green features into new developments, the government introduced two important practice notes: JPN1 (Joint Practice Note 1) and JPN2 (Joint Practice Note 2) in 2001 and 2002, respectively. The main aim of these Notes was to encourage developers to adopt a holistic life cycle approach for the entire construction process so as to minimize usage of nonrenewable energy and demolition waste. It was expected that these incentives would encourage developers to incorporate more green elements in the form of balconies, sky gardens and utility platforms. In 2003, demonstrating further commitment to a green building industry, two more important initiatives were taken by the government. First, the government established the indoor air quality management (IAQ) scheme, and second, the government established the "Council for Sustainable Development". This institution was expected to identify and advise the government on sustainable development priority areas. In order to promote public awareness of sustainability practices, the government also established a fund, known as the "Sustainable Development Fund" with a starting fund of HK\$ 100 million.

Some serious efforts by the private sector to promote green features and buildings are also evident in Hong Kong. For example, one of the very early initiatives was the "Business Environment Council (BEC)", established in 1989 , with the intention of promoting corporate sustainability (CS) and environmental sustainability (ES) (Business Environment Council [BEC], 2011). Another such private sector initiative established to promote sustainable development is the "Hong Kong Sustainable Development Forum", set up in 2001.
These intinitaves have increased public awareness of the importance of sustainable construction in Hong Kong and have lead to a variety of building assessment schemes to rate building environmental performance. Two wellknown examples are the HK-BEAM and BEAM Plus certification schemes, awarded by the HKBEAM Society Limited. Among these two professional certification schemes, on a per-capita basis HK-BEAM is the most commonly used voluntary building rating scheme of its kind in the world (BEC, 2011). As the most popular local building certification scheme in the industry, approximately 150 major property developments, including 36,000 housing units, have been certified by HK-BEAM for improved performance since its establishment. This scheme was greatly inspired by BREEAM (Building Research Establishment's Environmental Assessment Method) in the UK, (Jones Lang LaSalle, 2009). BEAM Plus, which was introduced in 2010, was a revamped version of BEAM. BEAM Plus widened the coverage of issues, further defining the quality and sustainability of building features (BEAM Society, 2012b). See Table 1 for a brief description of the assessment criteria of HK-BEAM and BEAM Plus. Another scheme, the HK-GBC award, was jointly, established in 2006, by the Professional Green Building Council (PGBC), the Construction Industry Council (CIC), and the Business Environment Council (BEC), and aims to promote the adoption of green building standards for a more sustainable Hong Kong.

These schemes are instrumental in quantifying the environmental impact of buildings. Green-labelling or certification schemes, however, are relatively new to the commercial office sector compared to the residential sector in Hong Kong. As shown in Table 2, out of the total green certification schemes, only $18 \%$ and $42 \%$ of new commercial properties have been certified by BEAM Plus and HKBEAM, respectively. In the case of LEED, however the figure is about $80 \%$ as LEED was designed mainly for commercial properties. However, not a single study has been conducted in Hong Kong focussinng on the impact of such schemes on commercial office property values, vacancies or rents. A comprehensive study focussing on the effects of eco-labelling of office buildings will help us understand whether buyers consider green certfication schemes as reliablein their ability to recognize the benefits of green office buildings, and hence are willing to pay premiums for such buildings.

\subsection{Green building certificates and property values}

Buildings that possess a green certification award are expected to bring various benefits to the tenants and to society equally, which include the use of low-resource renewable materials and lower $\mathrm{CO}_{2}$ emission, (Fuerst \& McAllister, 2011; Reed \& Wilkinson, 2008; Wilkinson, Reed, \& Cadman, 2008), healthy living space through cleaner air quality (Pitts \& Jacksons, 2008; Dunckley, 2007), the use of less water (Roper \& Beard, 2006), cost savings to tenants through the efficient use of energy (Reichardt et al., 2012; 
Table 1. Assessment criteria and benefits of HK-BEAM, BEAM Plus and LEED (sources: extracted from Mohammad and Amato (2006), Table 1; WBCSD (2008); Ahankoob, Morshedi, and Rad (2013); Hong Kong Green Building Council (2016); US Green Building Council (2016a))

\begin{tabular}{|c|c|c|}
\hline $\begin{array}{l}\text { Assessment } \\
\text { tool }\end{array}$ & Criteria & Benefits \\
\hline HK-BEAM & $\begin{array}{l}\text { Global issues and use of resources (energy efficiency, } \\
\text { deforestation and loss of biodiversity, ozone depletion, } \\
\text { environmental management, depletion of natural } \\
\text { resources) } \\
\text { Local issues (ecological impacts and landscaping, wind } \\
\text { and micro climate, noise/air/water impacts of operation, } \\
\text { construction management, waste management, and } \\
\text { waste conservation) } \\
\text { Indoor issues (thermal comfort, air quality, lighting, } \\
\text { noise, hazardous materials) }\end{array}$ & $\begin{array}{l}\text { Cost savings - more efficient use of energy and resources } \\
\text { (both construction and use of buildings) } \\
\text { Better buildings - provide healthy and productive } \\
\text { accommodation } \\
\text { Reduced risks - through best management practice } \\
\text { Effective markets - assurance of the green credentials } \\
\text { of the buildings and tenants and buyers are able to } \\
\text { communicate their preferences } \\
\text { Regulatory preparedness for both local and international } \\
\text { standards }\end{array}$ \\
\hline BEAM Plus & $\begin{array}{l}\text { Management (policies, procedures and strategies } \\
\text { implemented to ensure buildings are operated in a } \\
\text { sustainable manner) } \\
\text { Site aspects (site location, emissions from the site, } \\
\text { greenery, site amenities) } \\
\text { Materials and waste aspects (materials in (green } \\
\text { purchasing) and out (waste disposal) of the building) } \\
\text { Energy use (energy performance, energy management } \\
\text { and analysis, commissioning, energy efficient } \\
\text { improvement, enhancement) } \\
\text { Water use (quality and features that improve the } \\
\text { utilisation and reduce effluent) } \\
\text { Indoor environmental quality (health, comfort, or } \\
\text { well-being of the occupants, as well as aspects of } \\
\text { performance that improve quality and functionality) } \\
\text { Innovations and additions (introduces innovative } \\
\text { designs, construction or operational provisions that } \\
\text { enhance performance) }\end{array}$ & $\begin{array}{l}\text { Cost-savings through the more efficient use of energy and } \\
\text { resources } \\
\text { Increasing occupant satisfaction from healthy and } \\
\text { productive accommodation } \\
\text { Enhancing corporate profile and marketability to } \\
\text { potential building users } \\
\text { Providing a tool to improve purchaser choice and } \\
\text { information } \\
\text { Integrating local and international best practice into new } \\
\text { designs } \\
\text { Providing increased protection against environmental } \\
\text { liability } \\
\text { Establishing a clear direction for continuous improvement } \\
\text { and optimised performance }\end{array}$ \\
\hline LEED & $\begin{array}{l}\text { Water efficiency - indoor and landscaping water use } \\
\text { reduction and wastewater strategies } \\
\text { Energy and atmosphere - to ensure that energy- } \\
\text { efficient systems are installed, calibrated and customer's } \\
\text { desired results are provided by producing following } \\
\text { items, to minimize the level of energy consumption so } \\
\text { as to minimize environmental and economic impacts } \\
\text { resulting from excessive energy use and refrigerant } \\
\text { management to reduce stratospheric ozone depletion } \\
\text { Materials and resources - to use durable goods and } \\
\text { materials to minimize the effects on environment, } \\
\text { maintenance of facilities of buildings and to reduce the } \\
\text { degree of toxic waste } \\
\text { Innovation and design process } \\
\text { Indoor environmental quality - to enhance indoor to } \\
\text { improve and enhance the health and well-being of the } \\
\text { occupants }\end{array}$ & $\begin{array}{l}\text { Provide a competitive differentiator - sustainability } \\
\text { leads to market differentiation and improved financial } \\
\text { performance } \\
\text { Make for happier employees and occupants - increased } \\
\text { recruitment and retention rates and increased productivity } \\
\text { benefits for employers } \\
\text { Attract tenants - tenants understand and are looking for } \\
\text { the benefits that LEED-certified spaces have to offer } \\
\text { Save energy and resources, lower operating costs - firms } \\
\text { that built green to achieve lower operating costs and to } \\
\text { gain a branding/public relations advantage } \\
\text { Be cost-effective - LEED-certified facilities annually } \\
\text { opened up } 458 \text { more consumer deposit accounts and had } \\
\text { more consumer deposit balance per facility per year and } \\
\text { increased revenue } \\
\text { Provide public relations community benefits - not only } \\
\text { did it reap great publicity, but had garnered a net present } \\
\text { value return of almost } 20 \text { to one on its initial investment } \\
\text { Increase rental rates - the overall vacancy rate for green } \\
\text { buildings was } 4 \% \text { lower than for non-green properties } \\
\text { Optimize health - by bringing the good in and keeping } \\
\text { the bad out, LEED creates healthy spaces. Buildings that } \\
\text { optimize wellbeing are more important than ever }\end{array}$ \\
\hline
\end{tabular}

Table 2. Number of projects certified by green certifications (as of 1 March 2016) (sources: Hong Kong Green Building Council (2016); BEAM Society (2012a); US Green Building Council (2016b))

\begin{tabular}{|l|c|c|}
\hline & Total number of certified projects & Total number of projects in commercial sector \\
\hline BEAM Plus & 348 & 63 \\
\hline HKBEAM & 279 & 119 \\
\hline LEED & 174 & 139 \\
\hline
\end{tabular}


Fowler, Rauch, Henderson, \& Kora, 2011; Kats, 2003), and increased tenants' satisfaction through a healthy living environment (Miller, Progue, Gough, \& Davis, 2009). From the business point of view, the benefits include increased business productivity through best management practices and an improved corporate profile (Orlitzky, Schmodt, \& Rynes, 2003), increased employee productivity and retention rates of employees (Miller et al., 2009; Lucuik, 2005) and enhanced marketability to potential tenants. Various stakeholders, including the real estate business community now tend to believe that embracing sustainability elements within the heart of the business does enhance competitiveness and marketability (Jones Lang LaSalle, 2009). Thus, good green energy labelling certification can be regarded as providing an advantage over competitors.

For these economic, social and environmental benefits to be fully realized in the market, it is necessary for the benefits of green features to be presented as a total package to the real estate stakeholders (Shimizu, 2010).

Most of the literature concerning the economic implications of green labelling in commercial office properties is grounded in the US (Robinson et al., 2016; Robinson \& McAllister, 2015; Das \& Wiley, 2013; Kok, Miller, \& Morris, 2012; Fuerst \& McAllister, 2011; Eichholtz, Kok, \& Quigley, 2010). A significant number of studies have examined the extent to which property values are enhanced by the LEED and Energy Star (ES) certifications in the US commercial property market. In a recent study, Kok et al. (2012) found a $7.1 \%$ rental premium compared to non-LEED certified buildings. In another study of 6518 commercial buildings in Colorado, Gripne, Martel, and Lewandowski (2012) reported a $\$ 3.54 /$ square $\mathrm{ft}$. rent premium for LEED certified properties, and $\$ 2.87 /$ square $\mathrm{ft}$. for ENERGY-STAR properties. Using a mixed-methods approach, Philbrick, Scheu, and Evens (2014), in a study of the financial benefits of energy efficiency upgrades in multi-family residential buildings, reported a rental income premium of $\$ 0.34$ /square $\mathrm{ft}$. Fuerst and McAllister (2011) also found a 5\% rental premium for LEED-certified properties and 4\% for ENERGY-STAR (ES) properties. In a similar study, Das, Tidwell, and Ziobrowski (2011) investigated the rental rate dynamics of 123 green commercial office buildings in the Washington DC and San Francisco metropolitan areas. They found a rental premium of $2.4 \%$ for LEED certified properties in down markets, and a $0.1 \%$ premium for up markets, indicating that LEED certified properties maintain relatively stable rental rates in real estate down cycles. In their study of Class A Office Data from 46 US office markets (with 7,308 properties), Wiley et al. (2010) not only supported the fact that green buildings yield a rental premium, but they also found green buildings sustain significantly higher occupancy rates. They reported that LEED properties yield premiums of 15.2-17.3\%, and Energy Star labelled properties achieve 7.3-8.6\%. Another recent attempt by Fuerst and McAllister (2011) reported a price premium of $25 \%$ and $26 \%$ and a rental premium of $5 \%$ and $4 \%$ for LEED and ES, respectively. In 2009, the same authors, using a larger sample of 127 LEED and 662 ES-certified office properties, estimated a $35 \%$ and $31 \%$ price premium for LEED and ES, respectively, and around 6\% rental premium for both LEED and ES. The effects of green building schemes in the US has been studied by many other researchers.

A few non-US studies are also available in the literature. For example, a recently concluded study by Chegut et al. (2014) found a price (rent) premium of $14.7 \%$ for BREEAM-certified office properties in London (in comparison with non-certified properties). The same authors Chegut, Eichholtz, and Kok (2011), based on another UKbased green building scheme, Eco Homes, reported an 8\% price premium for EcoHomes properties, and a 16-20\% rental premium. Besides these well-known schemes, Hyland, R. C. Lyons, and S. Lyons (2013) studied a less-known "Ireland energy efficiency rating scheme". Results reveal that prices of high-energy efficient properties (grade A) are about $9 \%$ greater than low-rated (grade D) properties.

Nevertheless, comprehensive studies on green certification schemes of commercial properties in Asia have been limited to general discussion, except for one recent study focussed on the Shanghai office rental market (i.e. Hui, Chan, \& Yu, 2015). Their results, in line with western studies, suggest that office properties certified by LEED are $12.8 \%$ more valued than those of properties without LEED certification. The study reported in this paper is unique in the sense of being the first on commercial properties in Hong Kong, and a comprehensive in the high-rise context in Asia. This is significant as the Asian perception of living and working in a green environment differs substantially in substance from the Western perception. It is true that Asian appreciates the advantages of the green revolution, but there is a significant fear that a full pledge to the green philosophy may scamper the Asian economic revolution. In Asia, economics still supersedes sustainability goals; and factors such as location and accessibility may be the primary considerations rather than green features in the choice of a commercial buildings (Addae-Dapaah \& Chieh, 2011). This is in contrast to the West, where corporate and institutional investors highly appreciate green property space for reasons such as enhancement of public image (Orlitzky et al., 2003), enhanced employee productivity and less employee absenteeism (Miller et al., 2009), cost savings through efficient energy consumption (Fowler \& Rauch, 2008). Thus, understating of the Asian perspective in relation to the green premium is significant.

The literature on the financial implications of green labelling schemes generally indicates a positive correlation between green building certification schemes and property values in the market place. Nevertheless, very little market implication analysis of green-certified commercial office properties has taken place in Hong Kong. The authors' research is perhaps the first of its kind in Hong Kong, and contributes to the limited amount of Asian literature and offers some insights and references for the benefit of real estate stakeholders in the expanding Chinese office property market. The research may also help to arouse awareness of the financial implications of green certification and stimulate market sentiment towards green properties which in turn will increase the demand for green buildings in the market. 


\section{Methodology and data}

\subsection{The model}

To examine the financial implications of BEAM, BEAM Plus and LEED certifications on the value of rental office space in Hong Kong, the study deployed a hedonic price model through a fixed effects approach. Despite some weaknesses (assumptions), the hedonic model (HPM) is regarded as an effective tool in the area of property valuation analysis (Hui et al., 2015; Hui, Tse, \& Yu, 2017). For example, using HPM, the effects of structural attributes such as floor area, age and size of the unit, etc. (Tse \& Love, 2000), landfills (Nelson, J. Genereux, \& M. Genereux, 1993), views (Benson, Hansen, Schwartz, \& Smersh, 1998), and noise and air pollution (Espey \& Lopez, 2000) on residential property values have been well documented in the literature.

Rosen (1974) offered a formal conceptual interpretation of the hedonic functions. As described by Rosen (1974, p. 1), "goods are valued for their utility-bearing attributes or characteristics". Accordingly, the rental value of an office property is said to be a function of physical attributes $(P)$, locational attributes $(L)$, and neighbourhood attributes $(N)$. These main attributes can further be disintegrated into smaller characteristics such as size, location, floor area, floor level, view, floor-to-ceiling height etc. making the real estate property a heterogeneous commodity (Sirmans, Macpherson, \& Zietz, 2005). The hedonic model, in the form of linear regression modelling, is able to disaggregate the value of a property into quantifiable implicit prices for each individual attribute (Ki \& Wadu Mesthrige, 2010).

Thus, the standard HPM models the effects of physical $(P)$, locational $(L)$ and neighborhood $(N)$ attributes, plus the effect of environmental certification (GREEN), the main interests of this research, as follows:

$\operatorname{LnRENT}_{i t}=\lambda+\beta P_{i t}+\gamma L_{i t}+\dot{\mathrm{e}} N_{i t}+\Omega G R E E N_{i t}+\varepsilon_{i t}$,

where: $\beta$, $\gamma$ and e are coefficients that represent the implicit prices of the physical $(P)$; locational $(L)$ and neighborhood $(N)$ attributes of the property, respectively, under standard assumptions (Rosen, 1974). The main coefficient of interest (green certification) is $\Omega$; and $\varepsilon_{i t}$ is an error term. RENT is the rental prices of office units for 2009-2015. With the given data on physical, locational, neighborhood and green certification, the model estimation is quite straightforward. In the model, the coefficient $\Omega$ represents changes in property value due to green certification. It is hypothesized that obtaining green certification entails a rental premium for office properties, which enhances property values. An enhancement in rental premium is expected to occur because of the above advantages that green buildings possess.

Nevertheless, the estimates in equation (1) may be biased for various reasons. First, it is not rationale to assume in a cross-sectional study that estimated (observed) price/rental premia are only caused by green certification. There can be unobserved variables/characteristics that subsequently cause both certification and higher prices. For example, certified properties tend to have superior building features but two are not necessarily linked (Reichardt et al., 2012). Thus, one would expect relatively higher rents/prices in such properties even without certification. The second cause of potential bias are local trends. Having a certified building in the neighbourhood may bring positive price enhancements to the nearby properties. Such gentrification diverges the property values. This happens when property prices are not mean-reverting. In this case, the coefficient of green certification may be upward biased. Generally, anticipation of future property trends influences the current local property value. These local trends may have correlations with levels and trends in property values. Omitting local amenities therefore may lead to biased results. The final cause of potential bias is that property characteristics may change over time, causing changes to coefficients on characteristics. Thus, if we assume that these characteristics and respective coefficients remain unchanged (in equation 1), the coefficients of other variables would be biased.

Taking these issues into account, the error term of equation (1) was decomposed into two components: a component that is correlated with independent variables, $\vartheta_{i t}$ (see equation 2), and a component that is not correlated with independent variables, $\varepsilon_{i t}$.

$\operatorname{LnRENT} T_{i t}=\lambda+\beta P_{i t}+\alpha L_{i t}+\dot{\mathrm{e}} N_{i t}+\Omega G R E E N_{i t}+$ $\vartheta_{i t}+\varepsilon_{i t}$.

Omitting the component, $\vartheta_{i t}$ from the regression model would bias the estimates. In the model, $\vartheta_{i t}$ is expected to account for unobserved characteristics including local property value trends. The model therefore allows for controlling unobserved effects, and mitigating a potential omitted variable bias in the model. These types of fixed effects model are able to produce estimates of the dynamic behaviour of rental price premium over time (Reichardt et al., 2012). The approach to addressing such local trends was to add a control to the equation. Accordingly, to control for the systematic difference in rental price values between certified and non-certified properties and local property value trends, two observations were used for each property: one before certification and one after certification. An interaction term of fixed effects was also then included in the model (equation 3).

The proposed hedonic equation is:

$\operatorname{Ln}(\operatorname{RENT})_{i t}=\beta_{0}+\beta_{1}\left(\operatorname{GREEN}_{i t}\right)+\beta_{2}\left(\operatorname{GREEN}_{i t}{ }^{*} \mathrm{~T}_{i t}\right)+$ $\beta_{3} \operatorname{Ln}(\mathrm{AGE})_{i t}+\beta_{4} \operatorname{Ln}(\mathrm{AREA})_{i t}+\beta_{5} \operatorname{Ln}(\mathrm{FLOOR})_{i t}+$ $\beta_{6} \operatorname{Ln}(\mathrm{CEIL})_{i t}+\beta_{7}\left(\mathrm{R} \_ \text {FLOOR }\right)_{i t}+\beta_{8}\left(\mathrm{I}_{-} \mathrm{CPARK}\right)_{i t}+\beta_{9} L n$ $\left(\mathrm{D}_{-} \mathrm{CBD}\right)_{i t}+\beta_{10} \operatorname{Ln}$ (D_MTR) ${ }_{i t}+\beta_{11} \operatorname{Ln}$ (CLUSTER) ${ }_{i t}+$ $\beta_{12}\left(\mathrm{~B}_{-} \mathrm{VIEW}\right)_{i t}+\beta_{13} \operatorname{Ln}\left(\mathrm{S}_{-} \mathrm{VIEW}\right)_{i t}+\beta_{14}\left(\mathrm{VAC}_{i t-i}\right)+$ $\beta_{15}\left(\mathrm{UE}_{i t-4}\right)+C_{i}+C_{t}+\varepsilon_{i}$,

where: $L n(\text { RENT) })_{i t}$ is the logarithm of the rental price of an office unit. GREEN $i t$ is an indicator (dummy) variable, where it takes 1 if a property is certified (certified group), and 0 otherwise. Properties belong to the certified group if the transaction took place after the property had received certification. $T$ is also an indicatory variable, which takes 
1 if the rental price was measured after the green certification, 0 when the rental price was measured before the certification. The interaction variable $G_{R E E N} * T_{i t}$ captures the effects of certification on rental prices, and GREEN captures any separate effects of certification. The interaction variable is also capable of accounting for the effects of property characteristics that may change over time. To control for the past vacancy rates in buildings, a variable $V A C_{i t-i}$ was introduced in the model. Generally, property owners tend to adjust rents in response to past vacancy rates. Further, in order to control for the effects of economic conditions on property values, the unemployment rate $\left(U E_{t-4}\right)$ was also included in the model. Building fixedeffects $\left(C_{i}\right)$ were incorporated in the model to account for time-invariant attributes/variables. Likewise, $C_{t}$, which represents time-fixed effects, was included in the model to control for changes in macroeconomic conditions over time that may have influence on all properties. Details of other variables are shown in Table 3. A monthly price index, obtained from the Government's Rating and Valuation Department, was used to convert nominal rents into real rental values to remove inflation effects. The most important variable in the study is GREEN. This refers to those office buildings, which have been certified by HKBEAM, BEAM PLUS and LEED in Hong Kong. In addition to the main focussed variable, thirteen other important office property variables are incorporated in the model.

\subsection{Data description}

To investigate if buyers are willing to recognize the benefits by paying a premium for a green commercial of- fice unit, transaction records of office properties with and without green building certifications were studied. In 2010, there were 2327 commercial office buildings in Hong Kong (LegCo, 2010). Of these, 321, as of 2016, have been awarded green certifications, as seen in Table 2. A sample of 46 of these certified commercial office buildings, or $14.3 \%$, a good representation of the total population, from the three different districts of Central and Wanchai, Quarry bay and Kwun Tong, was selected for the study. Grade "A" office properties certified by HKBEAM, BEAM Plus and LEED were regarded as green buildings. 37 non-green buildings (without green certifications) within 150 meters of the selected certified green buildings (within the same geographic area as the certified properties), similar in age to green buildings, were also included in the sample. In the sample, no building has more than one certification. Properties with more than one certification are not common in Hong Kong. This is mainly because green certification is still not the norm in Hong Kong. Table 4 summarizes the attributes of the properties in the sample. The total number of valid office property transactions was 7697, and the transactions were obtained randomly from buildings in the sample. Further, any transaction was only counted once. The property transactions data for all properties (not-certified as well as certified) included such attributes as age, floor area, floor level, building view and sea view were obtained from Economics Property Research Centre (EPRC) Limited, Midland Realty and Centaline property consultants databases. EPRC, established in 1991, is a wholly owned subsidiary of Hong Kong Economic Times Holdings. The

Table 3. Description of property attributes in the model

\begin{tabular}{|c|c|c|c|c|}
\hline Attributes & Abbreviation & Characteristics & Definition & $\begin{array}{l}\text { Expected } \\
\text { sign }(+/-)\end{array}$ \\
\hline Rental price & $\operatorname{Ln}(R E N T)$ & $\begin{array}{l}\text { Unit transaction } \\
\text { rental price }\end{array}$ & $\begin{array}{l}\text { Real rental transaction price of the office unit }(\mathrm{HK} \$) \text { in } \\
\text { log form }\end{array}$ & I \\
\hline \multirow{6}{*}{$\begin{array}{l}\text { Physical/ } \\
\text { structural }\end{array}$} & $\operatorname{Ln}(A G E)$ & Building age & Age of the office unit in years in log form & - \\
\hline & $\operatorname{Ln}(A R E A)$ & Saleable floor area & Saleable area of the unit in square meters in log form & + \\
\hline & $\operatorname{Ln}($ FLOOR) & Floor level & Number of floors above the ground in log form & + \\
\hline & $\operatorname{Ln}(C E I L)$ & Ceiling height & $\begin{array}{l}\text { Ceiling height (the difference between the floor to } \\
\text { ceiling) in meters in log form }\end{array}$ & + \\
\hline & $R \_F L O O R$ & Raised floor & $\begin{array}{l}\text { A dummy variable: } 1 \text { if the unit has a raised floor; } 0 \\
\text { otherwise }\end{array}$ & + \\
\hline & I_CPARK & Internal car park & $\begin{array}{l}\text { A dummy variable: } 1 \text { if the building has an internal car } \\
\text { park; } 0 \text { otherwise }\end{array}$ & + \\
\hline \multirow[t]{3}{*}{ Location } & $\operatorname{Ln}\left(D_{-} C B D\right)$ & Distance to CBD & $\begin{array}{l}\text { Distance to central district from the property in meters } \\
\text { in log form }\end{array}$ & + \\
\hline & Ln (MTR_STATION) & $\begin{array}{l}\text { Distance to the } \\
\text { train (MTR) }\end{array}$ & $\begin{array}{l}\text { The minimum walking distance between office unit and } \\
\text { the nearest MTR station (measured in meters) }\end{array}$ & - \\
\hline & CLUSTER & $\begin{array}{l}\text { Situated in the } \\
\text { office cluster }\end{array}$ & 1 if the building is located inside a main office centre & + \\
\hline \multirow[t]{2}{*}{ Neighbourhood } & B_VIEW & Building view & 1 if unit has a building view and 0 if otherwise & - \\
\hline & S_VIEW & Sea view & 1 if unit has a sea view and 0 if otherwise & - \\
\hline $\begin{array}{l}\text { Green } \\
\text { certification }\end{array}$ & GREEN & $\begin{array}{l}\text { Green } \\
\text { certifications }\end{array}$ & $\begin{array}{l}1 \text { if the office building is BEAM, BEAM Plus or LEED } \\
\text { certified; } 0 \text { otherwise }\end{array}$ & $\begin{array}{c}\text { To be } \\
\text { estimated }\end{array}$ \\
\hline \multirow{2}{*}{$\begin{array}{l}\text { Market/ } \\
\text { macro-economy }\end{array}$} & $U E$ & Unemployment & Annual unemployment rate & - \\
\hline & $V A C$ & Vacancy rate & Grade A annual office vacancy rate & - \\
\hline
\end{tabular}


Table 4. Summary of building attributes

\begin{tabular}{|c|c|c|c|c|c|c|c|c|}
\hline \multicolumn{5}{|c|}{ Green buildings } & \multicolumn{4}{|c|}{ Non-green buildings } \\
\hline Building name & $\begin{array}{c}\text { Year of } \\
\text { completion }\end{array}$ & $\begin{array}{l}\text { No. of } \\
\text { storey }\end{array}$ & $\begin{array}{l}\text { Floor area } \\
\text { (Sq. } \mathrm{fts})\end{array}$ & $\begin{array}{c}\text { Year of } \\
\text { certification }\end{array}$ & Building name & $\begin{array}{c}\text { Year of } \\
\text { completion }\end{array}$ & $\begin{array}{l}\text { No. of } \\
\text { storey }\end{array}$ & $\begin{array}{l}\text { Floor area } \\
\text { (Sq. fts) }\end{array}$ \\
\hline Elite Centre & 2012 & 19 & 11875 & 2015 & Rykadan Capital Tw. & 2013 & 26 & 12000 \\
\hline Enterprise Square 3 & 2004 & 41 & 16100 & 2009 & T G Place & 2014 & 30 & 12732 \\
\hline $\begin{array}{l}\text { Enterprise Square Five - } \\
\text { Tower } 1\end{array}$ & 2007 & 15 & 18000 & 2009 & YHC Tower & 2013 & 32 & 12528 \\
\hline $\begin{array}{l}\text { Millennium City } 1 \text { Stan- } \\
\text { dard Chartered Tower }\end{array}$ & 1998 & 30 & 21449 & 2012 & $\begin{array}{l}\text { C-Bons International } \\
\text { Centre }\end{array}$ & 2009 & 20 & 16824 \\
\hline Sun Hung Kai Centre & 1982 & 54 & 16600 & 2011 & $\begin{array}{l}\text { Office Tower - } \\
\text { Convention Plaza }\end{array}$ & 1990 & 52 & 16518 \\
\hline Central Plaza & 1992 & 78 & 20000 & 2011 & Harbour Centre & 1983 & 33 & 14500 \\
\hline One Kowloon & 2006 & 39 & 23959 & 2014 & AXA Centre & 1982 & 26 & 12750 \\
\hline $\begin{array}{l}\text { Manulife Financial } \\
\text { Centre- Tower A }\end{array}$ & 2007 & 19 & 31378 & 2011 & Telford House & 1994 & 20 & 16300 \\
\hline $\begin{array}{l}\text { Manulife Financial } \\
\text { Centre- Tower B }\end{array}$ & 2007 & 20 & 31378 & 2011 & $\begin{array}{l}\text { Billion Centre - } \\
\text { Tower A }\end{array}$ & 2009 & 25 & 13815 \\
\hline The Rays & 2015 & 13 & 8587 & 2015 & Millennium City3 & 2002 & 26 & 8140 \\
\hline $\begin{array}{l}\text { Millennium City } 5 \text { - } \\
\text { BEA Tower }\end{array}$ & 2004 & 27 & 26000 & 2014 & MG Tower & 2011 & 21 & 29275 \\
\hline $\begin{array}{l}\text { Landmark East - AIA } \\
\text { Kowloon Centre }\end{array}$ & 2008 & 34 & 28000 & 2007 & EGL Tower & 2007 & 30 & 12029 \\
\hline $\begin{array}{l}\text { Landmark East - AXA } \\
\text { Tower }\end{array}$ & 2008 & 36 & 15000 & 2007 & $\begin{array}{l}\text { Kin Sang } \\
\text { Commercial Ctr. }\end{array}$ & 2013 & 23 & 6309 \\
\hline Pioneer Place & 2014 & 12 & 230000 & 2015 & Chuang's Tower & 1973 & 22 & 3940 \\
\hline $\begin{array}{l}\text { Standard Chartered } \\
\text { Bank Building }\end{array}$ & 1990 & 40 & 7500 & 2009 & 1 Lyndhurst Tower & 1994 & 22 & 3428 \\
\hline $\begin{array}{l}\text { One International } \\
\text { Finance Centre }\end{array}$ & 1998 & 39 & 20000 & 2011 & Asia Standard Tower & 1979 & 28 & 5621 \\
\hline $\begin{array}{l}\text { Two International } \\
\text { Finance Centre }\end{array}$ & 2003 & 88 & 24500 & 2011 & Century Square & 1984 & 20 & 4057 \\
\hline AIA Central & 2006 & 37 & 3300 & 2012 & 8 Wyndhamstreet & 1997 & 30 & 3586 \\
\hline Charter House & 2002 & 29 & 18500 & 2010 & China Building & 1978 & 23 & 8000 \\
\hline Man Yee Building & 1999 & 33 & 10600 & 2010 & Citibank Tower & 1992 & 50 & 17300 \\
\hline Prince's Building & 1965 & 29 & 20000 & 2012 & Crawford House & 1976 & 22 & 6001 \\
\hline Alexandra House & 1976 & 36 & 11000 & 2012 & 100 Queen's Road & 2006 & 25 & 6740 \\
\hline York House & 2006 & 14 & 8275 & 2012 & New World Tower 1 & 1978 & 41 & 13800 \\
\hline Edinburgh Tower & 1983 & 47 & 12500 & 2012 & The Centrium & 2001 & 41 & 4230 \\
\hline Gloucester Tower & 1980 & 47 & 2479 & 2012 & Bank of East Asia & 1990 & 25 & 7857 \\
\hline One Exchange Squ. & 1985 & 52 & 13000 & 2012 & Fortis Bank Tower & 1982 & 32 & 6350 \\
\hline Two Exchange Squ. & 1985 & 51 & 13000 & 2012 & Shui On Centre & 1987 & 32 & 6285 \\
\hline Three Exchange Squ. & 1988 & 33 & 11000 & 2012 & The Sun's Group Ctr & 1996 & 24 & 7388 \\
\hline Hong Kong ClubBldg & 1984 & 24 & 8688 & 2011 & Hopewell Centre & 1980 & 64 & 15450 \\
\hline Wing On House & 1967 & 31 & 15946 & 2012 & Time Square Tower2 & 1993 & 39 & 19000 \\
\hline Great Eagle Centre & 1983 & 25 & 13500 & 2009 & Berkshire House & 1998 & 28 & 13300 \\
\hline Sunlight Tower & 1998 & 34 & 10589 & 2016 & $\begin{array}{l}\text { Kornhill Plaza - } \\
\text { Office Tower }\end{array}$ & 1988 & 13 & 8750 \\
\hline 3 Pacific-Place-Pha3 & 2004 & 36 & 15000 & 2016 & China United Centre & 1997 & 31 & 13000 \\
\hline 28 Hennessy Road & 2012 & 28 & 4935 & 2012 & 633 King's Road & 2007 & 30 & 10045 \\
\hline China Resource Bldg. & 1983 & 39 & 20500 & 2011 & $\begin{array}{l}\text { Chinachem } \\
\text { Exchange Square }\end{array}$ & 1997 & 35 & 9432 \\
\hline Hysan Place & 2012 & 17 & 16000 & 2013 & $\begin{array}{l}\text { Prosperity Millennia } \\
\text { Plaza }\end{array}$ & 1999 & 32 & 8100 \\
\hline Oxford House & 1999 & 40 & 11300 & 2010 & Olympia Plaza & 1999 & 25 & 7683 \\
\hline Lincoln House-Taiko & 1998 & 23 & 14300 & 2010 & & & & \\
\hline Cambridge House & 2003 & 36 & 6767 & 2010 & & & & \\
\hline Devon House & 1993 & 29 & 27500 & 2010 & & & & \\
\hline Dorest House & 1994 & 39 & 14700 & 2010 & & & & \\
\hline One Island East & 2008 & 59 & 21550 & 2010 & & & & \\
\hline 1063 King's Road & 1999 & 31 & 3546 & 2010 & & & & \\
\hline Kerry Centre & 2010 & 32 & 16690 & 2009 & & & & \\
\hline AIA Tower & 1998 & 43 & 14280 & 2008 & & & & \\
\hline
\end{tabular}


main business focus is to provide property information to market-related industries. EPRC is the largest and most respectable property information provider in Hong Kong. Floor-to-ceiling heights were obtained from the building plans held by the Buildings Department. Walking distance to the MTR was measured using Google Map. Property transaction records related to the period $1^{\text {st }}$ January 2009 to $1^{\text {st }}$ September 2015. This is the most suitable period as BEAM Plus assessment mechanism was launched in 2010.

\section{Results and discussion}

Descriptive statistics of the property attributes in the model are summarized in Table 5. Table 6 gives the results of the HPM' estimates, which were then subjected to regression diagnostics. The estimates were corrected for heteroscedasticity based on White's heteroscedasticity consistent standard errors. The variance inflation factor (VIF) test was employed to test for multicollinearity problems in the model. The results showed that our model was free of multicollinearity problem. VIF figures varied from 1.09 to 2.39 (with Mean VIF 1.67) ${ }^{1}$, which is well below the conventional rule of thumb of 10 (Neter, Wasserman, \& Kutner, 1989). As reported in Table 6, all (except one) selected independent variables were statistically significant at the 1 and $5 \%$ levels. All the variables also, except one, carry the expected theoretical positive/negative signs. The explanatory power of the model, represented by $R^{2}$ of 0.798 , suggests that approximately $80 \%$ of the total variation in office rental value is explained by the chosen independent variables. This shows that the model performed well in explaining the variation of office rental value in the selected sample.

The most important subject of this study, GREEN ${ }^{*} \mathrm{~T}$ was found to be statistically significant at the $1 \%$ level, with a positive coefficient of 0.109 and $p$-value 0.000 . This means that if an office property is certified with HKBEAM, BEAM Plus or LEED, the rental value increases by $10.9 \%$. In other words, office tenants are happy to pay $10.9 \%$ more for an office unit with green features certified by HK-BEAM, BEAM Plus or LEED. More specifically, office properties possessing these environmental certifications are, in general, clearly valued by tenants, who are willing to pay $10.9 \%$ premium. The time fixed effect is also significant at the $5 \%$ level.

Besides GREEN, all the physical and locational attributes of the selected office properties (except B_VIEW) were also found to be statistically significant at the 1 and $5 \%$ levels. As for physical attributes, the results reveal that office rental values (RENT) are positively related with saleable area (AREA), floor level (FLOOR), floor-to-ceiling height (CEIL), indoor car-parking (I_CPARK) and raisedfloor (R_FLOOR). For locational attributes, rental value is positively related to distance to $\mathrm{CBD}$ (D_CBD), proximity to an office cluster (CLUSTER) and sea view (S_VIEW),
Table 5. Descriptive statistics of the office property data

\begin{tabular}{|l|c|c|c|c|}
\hline & Mean & $\sigma$ & Minimum & Maximum \\
\hline Ln (RENT) & 10.0741 & 0.9568 & 3.8500 & 10.9350 \\
\hline Ln (AGE) & 3.0176 & 0.6588 & 2.2500 & 4.2900 \\
\hline Ln (AREA) & 7.7566 & 0.8447 & 5.1245 & 9.8730 \\
\hline Ln (FLOOR) & 2.9127 & 0.6001 & 1.8100 & 3.9800 \\
\hline Ln (CEIL) & 0.9959 & 0.0557 & 1.0021 & 1.5510 \\
\hline R_FLOOR & 0.1820 & 0.3861 & 0.0000 & 1.0000 \\
\hline VAC & 0.4680 & 0.0024 & 0.0370 & 0.0620 \\
\hline I_CPARK & 0.8010 & 0.3991 & 0.0000 & 1.0000 \\
\hline Ln (D_CBD) & 1.7788 & 0.4406 & 0.6900 & 2.6400 \\
\hline Ln (D_MTR) & 1.2479 & 0.8949 & 0.3671 & 1.9780 \\
\hline Ln (CLUSTER) & 0.8780 & 0.3271 & 0.0000 & 1.0000 \\
\hline B_VIEW & 0.3950 & 0.4889 & 0.0000 & 1.0000 \\
\hline S_VIEW & 0.3950 & 0.4889 & 0.0000 & 1.0000 \\
\hline GREEN & 0.4150 & 0.4928 & 0.0000 & 1.0000 \\
\hline UE & 4.0638 & 0.0812 & 0.0370 & 0.0620 \\
\hline
\end{tabular}

Table 6. Results for the HPM

\begin{tabular}{|c|c|c|c|}
\hline Independent variable & Coefficient & t-statistic & p-value \\
\hline Constant & $1.182(0.540)$ & 2.188 & 0.0290 \\
\hline \multicolumn{4}{|l|}{ Physical attributes } \\
\hline $\operatorname{Ln}(A G E)$ & $0.108^{\star \star \star}(0.024)$ & 4.501 & 0.0000 \\
\hline $\operatorname{Ln}(A R E A)$ & $0.971^{\star * \star}(0.039)$ & 24.897 & 0.0000 \\
\hline $\operatorname{Ln}($ FLOOR) & $0.141^{\star * \star}(0.027)$ & 5.222 & 0.0000 \\
\hline $\operatorname{Ln}(C E I L)$ & $1.083^{\star * \star}(0.175)$ & 6.188 & 0.0000 \\
\hline R_FLOOR & $0.322^{\star * *}(0.053)$ & 6.075 & 0.0000 \\
\hline I_CPARK & $0.019^{\star \star}(0.009)$ & 2.117 & 0.0343 \\
\hline$V A C_{t-4}$ & $-0.032^{\star \star \star}(0.005)$ & -6.401 & 0.0000 \\
\hline \multicolumn{4}{|l|}{ Locational attribute } \\
\hline $\operatorname{Ln}\left(D \_C B D\right)$ & $-0.040^{\star \star}(0.016)$ & -2.442 & 0.0147 \\
\hline $\operatorname{Ln}\left(D \_M T R\right)$ & $-0.091^{\star \star \star}(0.019)$ & -4.789 & 0.0000 \\
\hline Ln (CLUSTER) & $0.028^{\star * \star}(0.012)$ & 2.333 & 0.0171 \\
\hline B_VIEW & $-0.005(0.009)$ & -0.588 & 0.5540 \\
\hline S_VIEW & $0.115^{\star * *}(0.021)$ & 5.476 & 0.0000 \\
\hline \multicolumn{4}{|c|}{ Environmental attributes } \\
\hline GRREN ${ }^{*} T$ & $0.109^{\star * \star}(0.019)$ & 5.746 & 0.0000 \\
\hline GREEN & $0.092^{\star \star \star}(0.013)$ & 7.076 & 0.0000 \\
\hline$U E_{t-4}$ & $-0.021^{\star *}(0.008)$ & -2.625 & 0.0170 \\
\hline$C_{t}$ & $-0.017^{\star *}(0.007)$ & 2.476 & 0.0130 \\
\hline$R^{2}$ & 0.798 & & \\
\hline $\operatorname{Adj.} R^{2}$ & 0.789 & & \\
\hline F-stat. & 2696 & & \\
\hline$N$ & 7697 & & \\
\hline
\end{tabular}

Notes: Robust standard errors are in parentheses; $(* * *)$, and $(* *)$ denote that the significant level $1 \%$, and $5 \%$, respectively.

1 The full VIF table is not reported in the study for space consideration, but will be available upon request. 
and negatively related with distance to the nearest MTR station (D_MTR). These findings are in line with the results of previous studies (e.g. Heinzle et al., 2013; Tse \& Love, 2000). However, though the age of the property was expected to be inversely related to rental value, the results suggest otherwise. This may be attributable to the fame of the office properties chosen for the study. All the selected buildings are grade $\mathrm{A}$ and most are located in prestigious areas with relatively old office properties, but with very good accessibility and the necessary support services. Building age, therefore, seems to be an irrelevant factor in this study sample. All three locations in the sample are premier office locations. Specifically, two of the three districts are prestigious office centres with relatively old office buildings. Except for Kwun Tong, there are substantial numbers of relatively old but prestige office buildings in clusters in the study area. The positive sign of the "Age" variable may be largely attributable to this locational factor. This result is in accordance with some previous findings (e.g. Ozus, 2009; Gat, 1998).

The positive coefficient of 0.141 (of FLOOR) suggests that for units of the same size, the higher the office is situated, the higher its value. This is very much relevant to a place like Hong Kong, where lower level units experience so much noise and air pollution. Tenants are willing to pay a premium for a better view and cleaner air. This finding is consistent with some previous office market research (e.g. Slade, 2000; Bollinger, Ihlandfeldt, \& Bowes, 1998). Similarly, a positive relationship was found between office rent and the saleable area of the office unit (AREA). This is expected and in line with previous studies, although few studies (e.g. Brennan, Cannaday, \& Colwell, 1984), suggest a negative relationship can exist since larger companies have greater bargaining power in lowering rent. However, as the Hong Kong office market is very dynamic and competitive, that bargaining power may not be so significant. As a larger office space facilitates effective business operation and enhances face-to-face interactions with clients, tenants are willing to pay more for a larger unit (Gat, 1998). The ceiling-to-floor height (CEIL) was also significant in the study, suggesting that tenants value offices with higher ceilings. It is said that a higher ceiling improves the office proportions giving employees a sense of spaciousness, which is psychologically uplifting. It might also provide additional storage (e.g., space for taller filing cabinets) compared to a low ceiling office unit, which feels cramped and closed in. Higher ceiling can improve space efficiency and enhance the workplace (Sev, Ozgen, \& Basarir, 2011), as they improve storage space and provide a sense of comfort to the eyes of employees. Likewise, the raised floor design (R_FLOOR) is another physical attribute found to have a positive effect on the rental value. Offices with newly designed raised floor systems are better able to accommodate new advanced technologies (such as electric and other HVAC cables and pipes), so that tenants are happy to pay more for such units. Similar to some previous studies (Mills, 1992; Hough \& Kratz, 1983), office units with internal car parking (I_CPARK) are highly val- ued compared to units without such parking. The findings reveal that the rental value of an office unit with parking facilities, in general, is $0.019 \%$ higher than that of a unit without such facilities in the sample office buildings.

As a significant locational/spatial attribute determining the rental price of an office unit, closer proximity to a good transportation mode has been documented in the literature (Ozus, 2009; Enström \& Netzell, 2007). The findings of this research study indicate that an increase in distance between the selected office unit and the nearest MTR Station decreases rental value. Closer proximity to a prestigious office cluster is another significant element determining the rental value of an office unit. The variable CLUSTER, which was found to be highly significant, implying that the rental price of an office unit closer to an office cluster is approximately $2.8 \%$ higher than that of a unit situated outside a cluster area. Lastly, a "view" influences the rental value of an office unit. Empirical results suggest that a unit with a sea view (S_VIEW) yields a rental premium of about $11.5 \%$ while a unit with a building view (B_VIEW) is not appreciated by potential clients, other things being equal.

\section{Propensity Score Matching (PSM)}

To check the robustness of variables, the PSM in the "MatchIt" package in R constructs (Ho, Imai, King, \& Stewart, 2011) was used for treatment effects estimation. Accordingly, a binary logistic regression model, using the same explanatory variables used in the fixed effects model, was used to estimate the propensity score. The employed matching method was that of 'optimal' matching. To investigate the potential treatment effect, means for each explanatory variable in full sample and matched sample were compared, and found that matching greatly enhances the balance of covariates. The treatment effect estimation revealed that the price value of certified properties (green properties) was $11.2 \%$ higher than those without certifications, ceteris paribus. This value premium estimation (provided by the PSM) is very much consistent with the fixed effects model regression results of 0.109 .

All in all, the empirical findings show clearly that tenants/users appreciate quality green office spaces certified with environmental certification schemes and are willing to pay a premium for those properties. Green-certified (HKBEAM, BEAM Plus or LEED) office buildings, in general, have rental values approximately $10.9 \%$ higher than buildings without such certification. This rental premium is very similar to that estimated, $16-20 \%$, by Chegut et al. (2011) in their UK study. The premium however is larger than some seen in previous US-based studies (e.g. Reichardt et al., 2012; Eichholtz et al., 2010; Fuerst \& McAlister, 2011). Possible reasons could be: (a) certified properties generally tend to also have better building features than to non-certified properties. Thus, the lack of control for these qualities could inflate the rental premium; (b) the green concept, especially green environmental certification schemes are relatively new to Asia and to Chinese territory. Therefore, not much information about the financial implications and possible impacts of the environmental 
Table 7. Green costs payback period (sources: (a) Cost data from Langdon and Seah (2018), "Quarterly construction cost review", various issues; (b) Rental data from "Hong Kong Property Reviews", Hong Kong Rating and Valuation Department (n.d.), various issues)

\begin{tabular}{|c|c|c|c|c|c|c|c|c|}
\hline \multirow{2}{*}{ Year } & \multirow{2}{*}{$\begin{array}{l}\text { Building cost }{ }^{\star} \\
\text { HK\$/Sq.ft. }\end{array}$} & \multirow{2}{*}{$\begin{array}{c}\text { Green development cost } \\
\text { (at } 7 \% \text { of total costs) } \\
\text { HK\$/Sq.ft. }\end{array}$} & \multicolumn{3}{|c|}{ Average rental price (HK\$/sq.ft.) } & \multicolumn{3}{|c|}{$\begin{array}{c}\text { Green costs payback period } \\
\text { (months) }\end{array}$} \\
\hline & & & $\begin{array}{c}\text { Central/ } \\
\text { Wan }\end{array}$ & QB & KT & $\begin{array}{l}\text { Central/ } \\
\text { Wanchai }\end{array}$ & QB & KT \\
\hline 2010 & 1808 & 126.6 & 58.7 & 30.1 & -- & 8.69 & 4.45 & --- \\
\hline 2011 & 1991 & 139.4 & 73.2 & 35.7 & -- & 10.83 & 5.28 & --- \\
\hline 2012 & 2374 & 166.2 & 80.2 & 38.0 & -- & 11.87 & 5.62 & --- \\
\hline 2013 & 2930 & 205.1 & 80.5 & 43.2 & 30.7 & 11.91 & 6.39 & 4.54 \\
\hline 2014 & 2944 & 206.1 & 79.5 & 44.4 & 32.2 & 11.77 & 6.57 & 4.77 \\
\hline 2015 & 3061 & 214.3 & 81.8 & 43.8 & 34.6 & 12.11 & 6.48 & 5.12 \\
\hline 2016 & 3107 & 217.5 & 87.7 & 47.4 & 34.9 & 12.98 & 7.02 & 5.17 \\
\hline 2017 & 3187 & 223.1 & 90.7 & 47.6 & 35.6 & 13.42 & 7.04 & 5.27 \\
\hline
\end{tabular}

Note: * high-rise office, prestige quality; $\mathrm{QB}=$ Quarry bay; KT = Kowloon Tong.

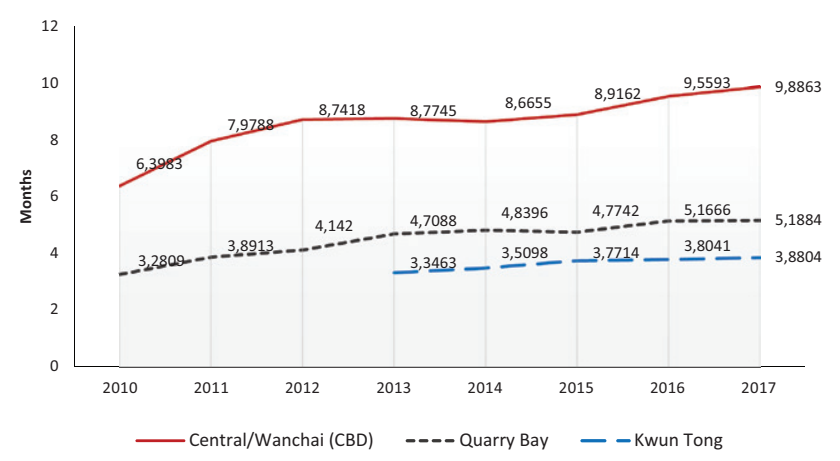

Figure 2. Green costs payback period (in months)

performance of buildings or green building certification schemes are readily available to real estate stakeholders. Hence, those investors (developers/owners) the first to adopt green properties are able to capitalize and tap into this new market without much competition, generating greater rental premiums; and (c) Hong Kong is a highdensity compact city with fewer green and open spaces, very different from the US and the UK contexts.

\section{Implications}

The findings hold practical implications for green building development in Hong Kong and elsewhere. Taking the rental premium as $10.9 \%$ for green certifications schemes and the average monthly rental of the study sample at $\mathrm{HK} \$ 76.2 / \mathrm{sf}^{2}$ into account, the study finds that the average monthly rent for green-certified (HKBEAM, BEAM Plus and LEED) office buildings is approximately $\mathrm{HK} \$ 8.31 / \mathrm{sf}^{2}$ greater. According to cost data available in Hong Kong, the green development cost premium for prime (grade A) office buildings is around $7 \%$ of the total cost, which averages around HK\$2650/sf (as of 2015) for high quality building. Based on this information, the additional cost of obtaining green certification is about 22 months of rent. In other words, the higher rental income generated by a certificated green building pays back the additional green development costs within about two years only.

The market implications of green certification are further explored in Table 7 and Figure 2. Taking the rental premium of $10.9 \%$ as the base, green development costs and pay back periods for the additional green costs were calculated for the period 2010-2017. The results indicate that the payback period is positively associated with time. This may be due to the increasing building costs over the years. Another most important finding is that the payback period is relatively high for properties located in the CBD compared to those some distance from the CBD. This finding is an incentive for investors and developers to invest in green properties.

\section{Conclusions}

The study, using a hedonic model, investigated the impact of the environmental certification schemes (HKBEAM, BEAM Plus, and LEED) on the rental price level for the grade A commercial office market in Hong Kong, one of the most dynamic commercial office markets in the region. Based on a sample of 67 commercial office buildings, the empirical findings suggest that certified commercial office properties yield a rental price premium of $10.9 \%$. The results suggest that office tenants/users do recognize the financial and other benefits of buildings of superior environmental performance and are willing to pay a premium for those properties when certified by recognized standard green environmental certification schemes. For example, a tenant is ready to pay $\mathrm{HK} \$ 54,500$ more for an office unit with green features (certified by the above schemes), on top of rental costs which would otherwise be $\mathrm{HK} \$ 500,000$.

A few important conclusions can be drawn. Firstly, that these certification schemes can be regarded as an impor- 
tant marketing tool for real estate investors and developers as they act as a guarantee of building quality performance. Thus, higher returns are guaranteed from such certified buildings, as properties certified by these schemes will enhance the corporate image of the owning companies particularly among environmentally friendly investors and tenants. Furthermore, as the empirical findings of this study favour the notion that green-certified properties can command a higher rental premium, the business case is well established for more and more stakeholders to embrace CSR thinking and attitudes at the heart of their businesses. Secondly, this revelation of higher returns/performance for environmentally friendly buildings can help overcome the prevailing scepticism concerning the financial implications of green buildings. Consequently, this should result in an increase in the supply of green buildings. Thirdly, though an awareness of the importance of green buildings prevails in society, in particular in the eyes of industry practitioners, the latter are not convinced of the financial value and this caution prevents green building development. The finding of this study, however, may help to overcome this caution as it affirms the benefits of green buildings, when certified by such as HKBEAM, BEAM Plus, and LEED. Perhaps the attitude towards green buildings in Hong Kong will move to a higher level.

The findings should convince the business community to take account of the environmental quality certification attached to a building when renting or buying. Tenants or users may see office properties certified by these schemes as having good quality environmental and building standards. Green environmental features can be treated as a property attribute as they add intrinsic value to the property, just as do some key physical attributes. In future, it can be expected that office rental prices will be influenced by the demand for and supply of green features. This suggests that rental incomes, vacancy rates, and the selling prices of commercial office properties will be positively influenced by property environmental and energy performance indicators. Hence, HK-BEAM, BEAM Plus, and LEED certification should be well received by the real estate community in Hong Kong. The business case for environmentally friendly buildings is therefore well proven.

\section{Acknowledgements}

The principal author, Wadu Mesthrige Jayantha, gratefully acknowledges the funding support given by the Hong Kong Polytechnic University (grant code: 4-ZZGC). The authors also would like to gratefully acknowledge the valuable comments given by the anonymous reviewers. A special thanks to Prof. Mike Anson for his editing and valuable comments on an earlier draft of this research paper.

\section{References}

Addae-Dapaah, K., \& Chieh, S. J. (2011). Green mark certification: does the market understand? Journal of Sustainable Real Estate, 3, 162-191.
Ahankoob, A., Morshedi, S. R. E., \& Rad, K. G. (2013). A comprehensive comparison between LEED and BCA green mark as green building assessment tools. The International Journal of Engineering and Science, 2(7), 31-38.

BEAM Society. (2012a). BEAM 4/04 \& 5/04 certified building. Retrieved from https://www.beamsociety.org.hk/en_beam_ assessment_project_4_detail.php?page $=26$

BEAM Society. (2012b). BEAM plus new buildings version 1.2. Retrieved from https://www.beamsociety.org.hk/files/BEAM_ Plus_For_New_Buildings_Version_1_2.pdf

Benson, E. D., Hansen, J. L., Schwartz, A. L. J., \& Smersh, G. T. (1998). Pricing residential amenities: the value of a view. Journal of Real Estate Finance and Economics, 16(1), 55-73. https://doi.org/10.1023/A:1007785315925

Bollinger, C., Ihlandfeldt, K., \& Bowes, D. (1998). Spatial variations in office rents within the Atlanta region. Urban Studies, 35(7), 1097-1118. https://doi.org/10.1080/0042098984501

Brennan, T. P., Cannaday, R. E., \& Colwell, P. F. (1984). Office rent in the Chicago CBD. Real Estate Economics, 12(3), 243260. https://doi.org/10.1111/1540-6229.00321

Business Environment Council. (2011). Leading responsible business. Retrieved from https://www.bec.org.hk/eng/corporate_ introduction.aspx

Castro, M. D. F., Mateus, R., \& Bragança, L. (2015). A critical analysis of building sustainability assessment methods for healthcare buildings. Environment, Development and Sustainability, 17(6), 1381-1412. https://doi.org/10.1007/s10668-014-9611-0

Chan, E., Esther, H. W., \& Yung, H. K. (2004). Is the development control legal framework conducive to a sustainable dense urban development in Hong Kong? Habitat International, 28(3), 409-426. https://doi.org/10.1016/S0197-3975(03)00040-7

Chegut, A., Eichholtz, P., \& Kok, N. (2011). The London commercial property price index. The Journal of Real Estate and Economics, 47(4), 588-616. https://doi.org/10.1007/s11146-013-9429-9

Chegut, A., Eichholtz, P., \& Kok, N. (2014). Supply, demand and the value of green buildings. Urban Studies, 51(1), 22-43. https://doi.org/10.1177/0042098013484526

Das, P., Tidwell, A., \& Ziobrowski, A. (2011). Dynamics of green rentals over market cycles: evidence from commercial office properties in San Francisco and Washington DC. Journal of Sustainable Real Estate, 3(1), 1-22.

Das, P., \& Wiley, J. A. (2013). Determinants of premia for energy efficient design in the office market. Journal of Property Research, 31(1), 64-86. https://doi.org/10.1080/09599916.2013.788543

Dimoudi, A., \& Tompa, C. (2008). Energy and environment indicators related to construction of office buildings. Resources, Conservation and Recycling, 53(1-2), 86-95. https://doi.org/10.1016/j.resconrec.2008.09.008

Dunckley, M. (2007). Green works wonders. The Australian Financial Review, 18, 1-57.

Eichholtz, P., Kok, N., \& Quigley, J. M. (2010). Doing well by doing good? Green office buildings. American Economic Review, 100, 2494-2511. https://doi.org/10.1257/aer.100.5.2492

Enström, R., \& Netzell, O. (2007). Can space syntax help us in understanding the intraurban office rent pattern? Accessibility and rents in Downtown Stockholm. The Journal of Real Estate Finance and Economics, 36(3), 289-305. https://doi.org/10.1007/s11146-007-9054-6

Environment Bureau. (2011). Council for sustainable development's public engagement on combating climate change: energy saving and carbon emission reduction in buildings. Hong Kong: Council for Sustainable Development.

Espey, M., \& Lopez, H. (2000). The impact of airport noise and proximity on residential property values. Growth and Change, 31(3), 408-419. https://doi.org/10.1111/0017-4815.00135 
Falkenbach, H., Lindhol, H., \& Schleich, H. (2010). Environmental sustainability: drivers for the real estate investor. Journal of Real Estate Literature, 18, 203-233.

Fowler, J., \& Rauch, E. M. (2008). Assessing green building performance: a post occupancy evaluation of 12 GSA buildings. Pacific Northwest National Library, Richland, Washington.

Fowler, K. M., Rauch, E. M., Henderson, J. W., \& Kora, A. R. (2011). Re-assessing green building performance: a post occupancy evaluation of 22 GSA buildings, Pacific Northwest National Laboratory. Washington.

Fuerst, F., \& McAllister, P. (2011). Eco-labeling in commercial office markets: do LEED and Energy Star office obtain multiple premiums? Ecological Economics, 70, 1220-1230. https://doi.org/10.1016/j.ecolecon.2011.01.026

Gat, D. (1998). Urban focal points and design quality influence rents: the case of the Tel Aviv office market. Journal of Real Estate Research, 16(2), 229-247.

Gomez, S. (2008). Is the client willing to pay to occupy a greener building? Frankfort: CB Richard Ellis.

Gorer, P., Lawson, A., Loh, C., Botelho, A. M. V., \& Leao, R. (2008). Green house or greenhouse? Climate change and the building stock of Hong Kong and Macau. Retrieved from https://www.admcf.org/wp-content/uploads/2016/12/1-Resource-k_-Green-House-or-Greenhouse-Civic-ExchangeApril-2008-.pdf

Gou, Z., \& Lau, S. S. Y. (2014). Contextualizing green building rating systems: case study of Hong Kong. Habitat International, 44, 282-289. https://doi.org/10.1016/j.habitatint.2014.07.008

Gripne, S., Martel, J. C., \& Lewandowski, B. (2012). A market evaluation of Colorado's high-performance commercial buildings. The Journal of Sustainable Real Estate, 4(1), 123-148.

Haapio, A., \& Viitaniemi, P. (2008). A critical review of building environmental assessment tools. Environmental Impact Assessment Review, 28(7), 469-482. https://doi.org/10.1016/j.eiar.2008.01.002

Heinzle, S. L., Yip, A. B. Y., \& Xing, L. Y. (2013). The influence of green building certification schemes on real estate investor behaviour: evidence from Singapore. Urban Studies, 50(10), 1970-1987. https://doi.org/10.1177/0042098013477693

Hong Kong Green Building Council. (2016). Statistics of BEAM Plus Projects. Retrieved from https://www.hkgbc.org.hk/eng/ BEAMPlusStatistics.aspx

Hong Kong Rating and Valuation Department (various issues). (n.d.). Annual property reviews. Retrieved from https://www. rvd.gov.hk/en/

HKSAR Development Bureau. (2011). Considerate Contractors Site Award Scheme. Retrieved from https://www.devb.gov. hk/en/construction_sector_matters/contractors/considerate_ contractors_site/index.html

Ho, D. E., Imai, K., King, G., \& Stewart, E. A. (2011). MatchIt: nonparametric preprocessing for parametric causal inference. Journal of Statistical Software, 42(8), 1-28. https://doi.org/10.18637/jss.v042.i08

Hui, C. M., Chan, E. W. F., \& Yu, K. H. (2015). The effect of LEED certification on Shanghai's prime office rental value. Journal of Facilities Management, 13(3), 297-310. https://doi.org/10.1108/JFM-10-2014-0033

Hui, E., Tse, C.-kin, \& Yu, K.-hung. (2017). The effect of BEAM Plus certification on property price in Hong Kong. International Journal of Strategic Property Management, 21(4), 384400. https://doi.org/10.3846/1648715X.2017.1409290

Hyland, M., Lyons, R. C., \& Lyons, S. (2013). The value of domestic building energy efficiency-evidence from Ireland. Energy Economics, 40, 943-952. https://doi.org/10.1016/j.eneco.2013.07.020
International Valuation Standards Council. (2017). International Valuation Standards. London, UK.

Jones Lang LaSalle. (2009). Is the Green Light on in Hong Kong? Retrieved from https://www.joneslanglasalle.com/MediaResources/ AP/Research/Research/paper-hk-2009-Sustainability.pdf

Kats, G. (2006). Greening America's schools: cost and benefits, Capital E Report. Retrieved from https://immobilierdurable. eu/images/2128_uploads/Kats_Green_schools_reprint.pdf

Kats, G. (2003). The costs and financial benefits of green buildings: California's sustainable building task force. Retrieved from https://www.usgbc.org/Docs/News/News477.pdf

Ki, C. O., \& Wadu Mesthrige, J. (2010). The effects of urban redevelopment on neighbourhood housing prices. International Journal of Urban Sciences, 14(3), 276-294. https://doi.org/10.1080/12265934.2010.9693685

Kok, N., Miller, N. G., \& Morris, P. (2012). The economics of green retrofits. Journal of Sustainable Real Estate, 4(1), 41-47.

Langdon and Seah. (2018). Quarterly construction cost review. Retrieved from https://images.arcadis.com/media/A/B/8/\%7BAB87AD80242E-4F02-BE2B-53B66A0E23C9\%7DHong\%20Kong\%20Quarterly\%20Construction\%20Cost\%20Review\%202018_.pdf

Lee, W., \& Burnett, J. (2008). Benchmarking energy use assessment of HK-BEAM, BREEAM and LEED. Building and Environment, 43(11), 1882-1891. https://doi.org/10.1016/j.buildenv.2007.11.007

LegCo. (2010). Profile of old buildings in Hong Kong. Retrieved from https://www.legco.gov.hk/yr09-10/english/hc/sub_leg/ sc05/papers/sc050209cb1-1163-1-e.pdf

Lucuik, M. A. (2005, March). A business case for the green buildings in Canada. Canada.

Metha, A. (2007, December 5). Towers of steel, feet of clay. The guardian, cities and climate change supplement. Retrieved from https://www.theguardian.com

Miller, N., Spivey, J., \& Florance, A. (2008). Does green pay off? Journal of Real Estate Portfolio Management, 14(4), 385-399.

Miller, N. G., Progue, D., Gough, Q. S., \& Davis, S. M. (2009). Green buildings and productivity. Journal of Sustainable Real Estate, 1(1), 65-90.

Mohammad, F., \& Amato, A. (2006). Public housing and social sustainability indicators: HK-BEAM as a case study. In COBRA 2006 proceedings of the construction and building research conference of the RICS. London: UCL.

Nelson, A. C., Genereux, J., \& Genereux, M. (1993). Price effects of landfills on housing values. Land Economics, 68(4), 359365. https://doi.org/10.2307/3146693

Neter, J., Wasserman, W., \& Kutner, M. H. (1989). Applied liner regression models (2 ed.). Homewood, IL: Richard D Irwin.

Orlitzky, M., Schmodt, F. L., \& Rynes, S. L. (2003). Corporate social and financial performance: a meta-analysis. Organization Studies, 24(3), 403-441. https://doi.org/10.1177/0170840603024003910

Ozus, E. (2009). Determinants of office rents in the Istanbul Metropolitan Area. European Planning Studies, 17(4), 621-633. https://doi.org/10.1080/09654310902811598

Philbrick, D., Scheu, R., \& Evens, A. (2014). Valuing the financial benefits of energy efficiency in the multifamily sector. Elevate Energy, US.

Pitts, J., \& Jackson, T. O. (2008). Green buildings: valuation issues and perspectives. The Appraisal Journal, 76(2), 115-118.

Raslanas, S., Kliukas, R., \& Stasiukynas, A. (2016). Sustainability assessment for recreational buildings. Civil Engineering and Environmental Systems, 33(4), 286-312.

https://doi.org/10.1080/10286608.2016.1236086 
Reed, R., \& Wilkinson, S. (2008). How green can you go? Increasing the value of your home through sustainability. Brisbane: John Wiley and Sons.

Reichardt, A., Fuerst, F., Rottke, N. B., \& Zietz, J. (2012). Sustainable building certification and the rent premium: a panel data approach. Journal of Real Estate Research, 34(1), 99-126.

RICS. (2008). Breaking the vicious circle of blame: making the business case for sustainable buildings. London: RICS.

Robinson, S., \& McAllister, A. (2015). Heterogeneous price premiums in sustainable real estate? An investigation of the relationship between value and price premiums. Journal of Sustainable Real Estate, 6, 1-20.

Robinson, S., Simons, R., Lee, E., \& Kern, A. (2016). Demand for green buildings: office tenants' stated willingness-to-pay for green features. Journal of Real Estate Research, 38(3), 423-452.

Robinson, S., \& Sanderford, A. (2016). Green buildings: similar to other premium buildings? Journal of Real Estate Finance and Economics, 52(2), 99-116. https://doi.org/10.1007/s11146-015-9498-z

Roper, K., \& Beard, J. (2006). Justifying sustainable buildings championing green operations. Journal of Corporate Real Estate, 8(2), 91-103. https://doi.org/10.1108/14630010610679899

Rosen, S. (1974). Hedonic prices and implicit markets: product differentiation in pure competition. Journal of Political Economy, 82(1), 34-55. https://doi.org/10.1086/260169

Sev, A., Ozgen, A., \& Basarir, B. (2011). Design criteria for highrise buildings in historical cities: the case of Istanbul (CTBUH Research Paper). Retrieved from https://www.ctbuh.org/papers

Sirmans, G. S., Macpherson, D. A., \& Zietz, E. N. (2005). A composition of hedonic models. Journal of Real Estate Literature, 13(1), 3-43.
Shimizu, C. (2010). Will green building be appropriately valued by the market? In Environment and real estate investment. The Economic of Value of Green Buildings: Part 2. Japan: Tokio Martine Property Investment management Inc.

Tse, R. Y. C., \& Love, P. E. D. (2000). Measuring residential property values in Hong Kong. Property Management, 18(5), 366374. https://doi.org/10.1108/02637470010360669

US Green Building Council. (2016a). LEED. Retrieved from https://leed.usgbc.org/leed.html

US Green Building Council. (2016b). Project Directory. Retrieved from https://www.usgbc.org/projects

Wadu Mesthrige, J., \& Wan, S. M. (2013). Effect of green labelling on residential property price: a study in Hong Kong. Journal of Facilities Management, 11(1), 31-51. https://doi.org/10.1108/14725961311301457

WBCSD. (2008). Collaborative action for energy regional network case study: Hong Kong BEAM: green building label. Retrieved from https://oldwww.wbcsd.org/DocRoot/EDlu2NXcBS MEJrKtBKHJ/hk-beam.pdf

Wetering, J. V., \& Wyatt, P. (2011). Office sustainability: occupier perceptions and implementation of policy. Journal of European Real Estate, 4(1), 29-47. https://doi.org/10.1108/17539261111129452

Wiley, J. A., Benefield, J. D., \& Johnson, K. H. (2010). Green design and the market for commercial office space. Journal of Real Estate Finance and Economics, 41(2), 228-243. https://doi.org/10.1007/s11146-008-9142-2

Wilkinson, S., Reed, R., \& Cadman, D. (2008). Property development. London: Taylor and Francis.

Yan, H., Shen, Q., Fan, L. C. H., Wang, Y., \& Zhang, L. (2010). Greenhouse gas emissions in building construction: a case study of one Peking in Hong Kong. Building and Environment, 45, 949-955. https://doi.org/10.1016/j.buildenv.2009.09.014 